\section{The application of Box-Cox transformation to determine the Standardised Precipitation Index (SPI), the Standardised Discharge Index (SDI) and to identify drought events: Case study in Eastern Kujawy (Central Poland)}

\author{
Arkadiusz BARTCZAK ${ }^{1) \text { ABCDEF }}$, Ryszard GLAZIK ${ }^{2) A D E}$, \\ Sebastian TYSZKOWSKI ${ }^{1)}$ ADE
}

\begin{abstract}
1) Polish Academy of Sciences, Institute of Geography and Spatial Organization, Department of Environmental Resources and Geohazards; Kopernika 19,87-100 Toruń, Poland; e-mail: arekbartczak@gazeta.pl, sebtys@wp.pl

${ }^{2)}$ Nicolaus Copernicus University, Institute of Geography, Department of Hydrology and Water Management, Gagarina 9, 87-100 Toruń, Poland
\end{abstract}

For citation: Bartczak A., Glazik R., Tyszkowski S. 2014. The application of Box-Cox transformation to determine the Standardised Precipitation Index $(S P I)$, the Standardised Discharge Index $(S D I)$ and to identify drought events: Case study in Eastern Kujawy (Central Poland). Journal of Water and Land Development. No. 22 p. $3-15$.

\begin{abstract}
The article presents the results of research into the transformation of series of hydro-meteorological data for determining dry periods with the Standardised Precipitation Index (SPI) and the Standardised Discharge Index $(S D I)$. Time series from eight precipitation stations and five series of river discharge data in Eastern Kujawy (central Poland) were analysed for 1951-2010. The frequency distribution of the series for their convergence with the normal distribution was tested with the Shapiro-Wilk test and homogeneity with the Bartlett's test. The transformation of the series was done with the Box-Cox technique, which made it possible to homogenise the series in terms of variance. In Poland, the technique has never been used to determine the SPI. After the transformation the distributions of virtually all series complied with the normal distribution and were homogeneous. Moreover, a statistically significant correlation between the $\lambda$ transformation parameter and the skewness of the series of monthly precipitation was observed. It was similar for the series of mean monthly discharges in the winter half-year and the hydrological year. The analysis indicates an alternate occurrence of dry and wet periods both in case of precipitation and run-offs. Drought periods coincided with low flow periods. Thus, the fluctuations tend to affect the development of agriculture more than long-term ones.
\end{abstract}

Key words: Box-Cox transformation, Eastern Kujawy, Gaussian distribution, meteorological drought, moving trend, SDI, SPI, variance homogeneity

\section{INTRODUCTION}

One should not adopt a negligent attitude to the process of analysis of series of data, particularly those of the environmental type. Special care is required at the initial stage of the analysis process, i.e. proper data preparation for further investigation. Provided that the theoretical assumptions concerning the selec- tion of the statistical method for the series analysis are met, one can presume that the obtained results and conclusions are correct. If, however, these assumptions are violated, several possible options arise. SAKIA [1992] sets forth a number of solutions. Following his approach, one can completely ignore the initial assumptions and continue with the analysis process as though they were met - how to interpret 
the results at which we arrive is the question that one has to face though. Another possibility is the development of a new model which will be true to all the initial assumptions. It is also necessary to turn to alternative proceedings of statistical analysis, e.g. apply non-parametric statistics which does not require any initial assumptions.

The normal data distribution pattern, along with the homogeneity of the series, is frequently the fundamental assumption. If one should be inclined to presume that the distribution pattern of the series of data is not normal, he/she ought to attempt to find the method that will make the distribution pattern normal or close-to-normal. An obstacle of this type usually occurs when it is necessary to select an appropriate transformation in order to obtain the highest possible accuracy of calculations, thus the highest accuracy of the results. The mechanism behind this process is based on the selection of a proper transformation and transforming each element of the series. Therefore, if one has $n$ number of observations of the investigated variable $x\left(x_{1}, x_{2}, x_{3}, \ldots, x_{n}\right)$ (and each transformed variable is denoted as $u$ ), after the transformation one shall obtain the series of $\left(u_{1}, u_{2}, u_{3}, \ldots, u_{n}\right)$. Analyses of various variable distribution transformation techniques to the normal pattern were provided by BARTLETT [1947], HOYLE [1973] or STRUPCZEWSKI [1967]. Typical, practically applied transformations include: logarithmic, root, hyperbolic, power, logit and many others.

Series of environmental variables most frequently display asymmetric distribution patterns with various levels of skewness and various kurtosis. By nature, the series of precipitation data are skewed positively which derives from the fact that they do not take negative values and are not in any way limited in the positive value area [TWARDOSZ, WALANUS 2011]. In most cases, the number of low values is larger than that of high values, consequently, the "right arm" of the distribution pattern will be longer. Distributions of 24-hour precipitation are characterised by the highest skewness, distributions of monthly precipitation are less skewed and distributions of annual precipitation display the lowest levels of skewness. The distribution pattern of a 24-hour period precipitation can be, with high approximation, described by means of the exponential distribution [DINGENS, STEYAERT 1971; Mitosek 1997; Twardosz, Walanus 2011]. The distribution of annual precipitation, following observations by DINGENS, STEYAERT [1971], KOŻUCHOWSKI [1985], is close to the normal distribution pattern. This conclusion is also confirmed in the research by BARTCZAK et al. [2013] performed for the series of annual precipitation in Eastern Kujawy, Poland. Therefore, it should be a foregone conclusion that the distribution patterns for monthly precipitation will occupy the space between the exponential distribution and the normal one. KENDALL [1960] states that the empirical distribution of monthly precipitation can be described by the incomplete gamma dis- tribution or the gamma distribution. Analysing the series of annual maximum daily rainfall in Central Poland (29 series from the period 1966-2010) KREŻAŁEK et al. [2013] argued that they can be represented by four types of probability distribution: Weibull, log-gamma, gamma and log-normal.

Like precipitation series, hydrological series can also display a larger or smaller levels of skewness. A particularly close consideration is given to the distribution patterns of the extreme discharges - maximum and minimum. On their basis situations which pose threat to human are analysed and modelled. The maximum discharges are the basis for analysing and modelling of floods, whereas the minimum discharges serve to analyse and model low water and hydrological drought events. A detailed analysis of statistical distributions of extreme monthly, half-yearly and yearly discharges for rivers in central Poland was presented by JOKIEL [2007] whose research indicated that series of monthly extremes were characterised by various distribution patterns (gamma, log-gamma, log-normal and Weibull). Moreover, it would be problematic to indicate any order or clear pattern in their seasonal distribution. For snowmelt-induced high flow months (February-April) the gamma and Weibull distribution patterns are most frequent, while in summer high flow months (June-August) these are the gamma and log-gamma ones. In the case of the series of monthly minimums, most are described with Weibull distribution. As for the 24-hour discharge, SEN, NIEDZIELSKI [2010] described those values for the Oder River by means of five parameters of Wakeby distribution mostly applied to describe extreme hydro-meteorological series - the maximum values of precipitation and discharge (e.g. GRIFFITHS [1989], PARK et al. [2001], Su et al. [2009]).

The time during which the research is performed seems to be of significant importance for the skewness parameter of a series. The shorter the period the larger the skewness. The reverse is also true: lengthening of the research time results in a series being less skew [KENDALL 1960].

It is a frequent occurrence that transformations result in the variance being simultaneously adjusted and constant in the transformed series. Constant variance is not dependent on the observation value or the series length [HOYLE 1973], which means that the series have constant variance in relation to the changing mean value.

The main objective of this work was to adopt the best, and at the same time, the most precise technique of bringing the distribution of precipitation and river outflow series to, or close to, the normal distribution. The above-presented analysis of reference material has indicated that the distribution patterns of hydrometeorological data series vary and that various complex analytical techniques are applied to determine them. The very process of series transformation, however, is not given a thorough consideration, as it is sufficient to know that the result of the test of the se- 
ries being compliant or normally-distributed after the transformation is satisfactory. The accuracy of the transformation, and hence the accuracy of the results obtained in the subsequent analysis, is not always checked.

The abovementioned research has been done because the standard normal distribution implies a number of interesting and practical properties such as:

1) the random variable takes the value within the range $-\infty ;+\infty$ and is not limited on either extreme.

2) the normal distribution is symmetrical; the axis of symmetry is determined by the following values: mean, median and mode which are located at the same point of the distribution.

These properties have been used to evaluate the intensity of a meteorological drought with the help of the SPI (Standardised Precipitation Index). According to $\mathrm{LABE} D Z K I$, BAK [2002], the index is "one of the many objective criteria for drought evaluation". It is utilised to detect dry periods and evaluate their intensity. The SPI for a given area is determined on the basis of long precipitation series for desired periods of time. MCKEE et al. [1993], however, as one of the properties of the index indicate the possibility of using it for other hydro-climatic characteristics e.g. river discharges, snow cover, soil humidity, level of ground water etc. What is more, owing to the application of the standard normal distribution and its properties the index enables comparison of the investigated characteristics within the framework of the same climate as well as the same characteristics in different climate zones. It is recommended by the Polish hydrological and meteorological service as the drought monitoring index. It has been used to identify and evaluate the intensity of drought events among others in Poland [BĄK, ŁABĘDZKI 2002; ŁABĘDZKI 2004; 2007; ŁABĘDZKI et al. 2008], Germany [KHADR et al. 2009], Sicily [BONNACORSO et al. 2003], Portugal [COSTA 2011; PAUlO et al. 2012], Greece [CARAVITIS et al. 2011], USA [GUTTMAN 1999; MCKeE et al. 1993], Pakistan [KHAN, GADIWALA 2013], Bangladesh [JAHANGIR AlAm et al. 2013], Africa [DUTRA et al. 2013]. Professional literature provides various techniques of SPI calculating with two of them being the most popular:

The first one relies on determining the parameters of probability distribution with maximum likelihood method followed by calculating the probability of the precipitation sum in the series for the distribution not being exceeded. Finally, the values of the variable with normal standardised distribution is calculated for the given probability [ŁABĘDZKI 2006].

The other technique requires a selection of a proper function to transform a series of precipitation to normal or close-to-normal distribution. According to ŁABĘDZKI and BĄK [2002] and ŁABĘDZKI et al. [2008] the best transformations for this purpose are: for monthly sums $\sqrt[8]{P}$ or $\ln P$, and for multi-decade ones $\sqrt[2]{P}, \sqrt[s]{(P+1)}, \sqrt[s]{(P+10}$ or $\ln P$.

\section{STUDY AREA AND DATA}

The study area - the eastern part of Kujawy, is a region in central Poland. This is a very specific area as, on the one hand, it is characterised by a negative structure of the water balance - it has some of the lowest precipitation and specific run-off records in Poland (particularly in the growing season) [BARTCZAK 2007; BARTCZAK, BRYKALA 2010; BARTCZAK et al. 2013; BRYKAŁA 2009; GIERSZEWSKI 2000], on the other hand, however, it is a predominantly agricultural region. Preparing the area for agricultural use required intensive land improvement efforts. Nevertheless, these works were of a specific, one-sided character. Aimed at lengthening the growing season, the amelioration works were concentrated on faster water drainage after the spring snow-melt. The analyses and research conducted by BRENDA [1997] have shown that this is the water deficit that hampers the agricultural development in the area. The highlyvaried and unique system of the environmental conditioning along with human activity have prompted detailed studies of this area. The basin of the Zgłowiączka River has been given a particularly thorough consideration becoming a testing-ground for detailed hydrological study performed by the authors in the period 2010-2013. The identification of wet and dry periods between 1951-2010 was one of the set objectives. The analyses were based on two data series concerning the discharge of the Zgłowiączka River as well as that of its largest tributary - the Lubieńka River. However, to cater for the requirements of this article, and for the sake of verification of the obtained results the scope of research has been enlarged to use the series of data on the discharge of the following rivers: the Skrwa Lewa (the catchment adjacent in the east), the Noteć (the catchment adjacent in the south) and the Tazżyna (the catchment adjacent in the west). The analysis of the series of precipitation data was conducted on the basis of eight precipitation stations. The location of the water-gauge and precipitation stations has been presented in Fig. 1. All of the stations are included in the gauging network of the Institute of Meteorology and Water Management in Warsaw, Poland.

Rather than the calendar year (January to December), as it is normally assumed in standard climate studies, the series of precipitation data cover the hydrological year (November to October). For each station, the analysis was conducted for monthly, halfyearly (XI-IV - the winter season, V-X - the summer season), yearly and seasonal (IV-IX - growing season) series. As a result, the analysis of 16 series was performed for each station (water-gauge and precipitation). Table 1 depicts the time span of the used data. The time span for most series encompassed extreme periods (wet and dry) both regarding the precipitation and the river run-off, which guarantees the data variety in the studied series. 


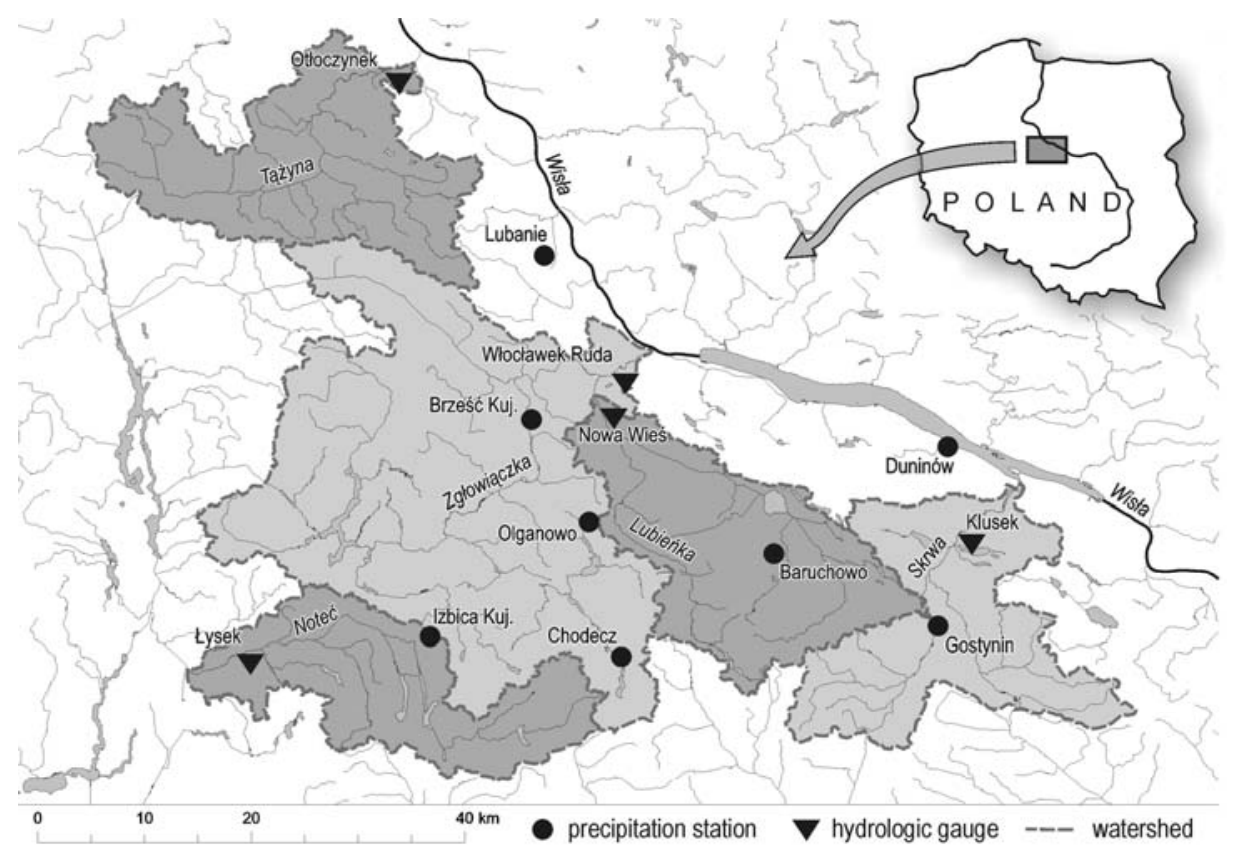

Fig. 1. Research area and location of precipitation stations and hydrologic gauges; source: own elaboration

Table 1. Time span of series of data assumed for analyses

\begin{tabular}{|c|c|c|c|}
\hline \multicolumn{2}{|c|}{ Precipitation station } & \multicolumn{2}{|l|}{ Rivers } \\
\hline Chodecz & $\begin{array}{l}1952-2010 \\
(59 \text { years })\end{array}$ & $\begin{array}{l}\text { the Zgłowiączka } \\
\text { (Włocławek Ruda gauge) }\end{array}$ & $\begin{array}{l}1951-2010 \\
(60 \text { years) }\end{array}$ \\
\hline Baruchowo & $\begin{array}{l}1951-2010 \\
(60 \text { years })\end{array}$ & $\begin{array}{l}\text { the Lubieńka } \\
\text { (Nowa Wieś gauge) }\end{array}$ & $\begin{array}{l}1951-1988 \\
\text { (38 years) }\end{array}$ \\
\hline $\begin{array}{l}\text { Izbica } \\
\text { Kujawska }\end{array}$ & $\begin{array}{l}1951-2010 \\
(60 \text { years })\end{array}$ & $\begin{array}{l}\text { the Skrwa Lewa } \\
\text { (Klusek gauge) }\end{array}$ & $\begin{array}{l}1961-2010 \\
(50 \text { years })\end{array}$ \\
\hline Duninów & $\begin{array}{l}1957-2010 \\
(54 \text { years })\end{array}$ & $\begin{array}{l}\text { the Noteć } \\
\text { (Lysek gauge) }\end{array}$ & $\begin{array}{l}1965-2007 \\
(43 \text { years })\end{array}$ \\
\hline Gostynin & $\begin{array}{l}1955-2004 \\
(50 \text { years })\end{array}$ & $\begin{array}{l}\text { the Tążyna } \\
\text { (Otłoczynek gauge) }\end{array}$ & $\begin{array}{l}1965-2010 \\
(46 \text { years) }\end{array}$ \\
\hline Lubanie & $\begin{array}{l}1955-1994 \\
(40 \text { years })\end{array}$ & & \\
\hline $\begin{array}{l}\text { Brześć } \\
\text { Kujawski }\end{array}$ & $\begin{array}{l}1955-1991 \\
(37 \text { years) }\end{array}$ & & \\
\hline Olganowo & $\begin{array}{l}1960-1991 \\
(32 \text { years) }\end{array}$ & & \\
\hline
\end{tabular}

Source: own elaboration.

\section{METHODS}

The research procedure and methods applied in the work.

1. The studied series were tested for their convergence with the normal distribution with the Shapiro-Wilk test and for their homogeneity with the Bartlett's test,

2. Normalisation of studied series.

The transformation of the random variable $x$ with density function $f(x)$ into a random variable with density function $f(u)$ with normal or close-to-normal distribution is referred to as normalisation of the random variable $x$. Out of numerous methods of series transformation, the Box-Cox technique [Box, Cox 1964; 1982] was selected for the sake of this work:

$$
u^{(\lambda)}= \begin{cases}\frac{x^{\lambda}-1}{\lambda} & (\lambda \neq 0) \\ \ln x & (\lambda=0)\end{cases}
$$

The above is a power or logarithmic transformation. It is true if each element of the series is greater than 0 . This condition, however, can be made obsolete by an appropriate shift of data. What is sought with this kind of transformation is such $\lambda$ parameter so that after the transformation with this parameter $\lambda$ the empirical distribution maximally approximates the normal distribution pattern. Methodically, this parameter is found by checking for which $\lambda$ the correlation coefficient of the quantiles of the series distribution after the transformation with the quantiles of the normal distribution is the highest. Theoretically, the $\lambda$ parameter can take the values of any sign. Therefore, it should be assumed that the series calibration towards the normal distribution does not depend on the direction of skewness.

As it can be observed, the Box-Cox method belongs to the family of transformations including numerous basic and commonly-applied transformations such as [OSBORNE 2010 extended]:

$\lambda=1.00 \rightarrow \frac{x^{1}-1}{1}=x-1-$ no transformation needed; procedures result identical to original data,

$\lambda=0.50 \rightarrow \frac{\sqrt{x}-1}{0.5}=2 \sqrt{x}-2$ - square root transformation,

$\lambda=0.33 \rightarrow \frac{\sqrt[8]{x}-1}{0.33}=3.33 \sqrt[8]{x}-3.33-$ cube root transformation,

$\lambda=0.25 \rightarrow \frac{\sqrt[4]{x}-1}{0.25}=4 \sqrt[4]{x}-4-$ fourth root transformation,

$\lambda=0.00 \rightarrow \ln x-$ natural $\log$ transformation, 
$\lambda=-0.25 \rightarrow \frac{\frac{2}{4 \frac{x}{x}}-1}{-0.25}=-\frac{4}{\sqrt{x}}+4-$ reciprocal fourth root transformation,

$\lambda=-0.33 \rightarrow \frac{\frac{1}{\sqrt[8]{x}}-1}{-0.37}=-\frac{z}{\sqrt{x}}+3.33-$ reciprocal cube root transformation,

$\lambda=-0.50 \rightarrow \frac{\frac{2}{\sqrt{x}}-1}{-0.5}=-\frac{2}{\sqrt{x}}+2-$ reciprocal square root transformation,

$\lambda=-1.00 \rightarrow \frac{x^{-1}-1}{-1}=-\frac{1}{x}+1-$ inverse transformation.

It should be also mentioned that the Box-Cox transformation is widely used in a number of fields of science. Apart from climatology (e.g. HE et al. [2013]), hydrology (e.g. THYER et al. [2002]) it is used in e.g. econometrics [NELSON, GRANGER [1979], biology [PELTIER et al. 1998] and others.

3. Following the normalisation process the series were re-checked for their convergence with the normal distribution with the Shapiro-Wilk test and for the homogeneity of the variance with the Bartlett's test.

4. Standardisation.

Standardisation is also a type of a linear transformation of a series with the distribution which is close-to or of normal pattern $u \sim N\left(n, \sigma^{2}\right)$, the result of which is a series with the mean of 0 and with standard deviation of 1 . The transformation is as follows:

$$
\frac{u-\bar{u}}{\sigma_{u}} \sim N(0,1)
$$

The process of standardisation is aimed at limiting the infinitely numerous normal variables to one standard. In other words, standardisation enables the comparison of a number of series characterised by various input data - both in respect of their scale and the unit of measurement.

5. Trend determination

The trends of normalised and standardised precipitation and river discharge values have been depicted with the use of a moving trend (segment, crawling). This method is particularly useful for the analysis of long series characterised by irregular and numerous changes in the direction of the trend within the series. The moving trend does not have the analytical form of a mathematical function.

Smoothing of a series is about an arbitrary determination of the smoothing constant $k(k<n)$ and then estimation of structural parameters of the linear function of the trend on the basis of subsequent fragments of the series with the length of the constant $k$. For a chronological series $y_{1}, y_{2}, \ldots, y_{n}$ and the smoothing constant $k$, the subsequent fragments of the series are:

$$
\begin{aligned}
& y_{1}, \ldots, y_{k} \\
& y_{2}, \ldots, y_{k+1} \\
& \ldots \ldots \ldots \ldots . . . \\
& y_{n-k+1}, \ldots, y_{n}
\end{aligned}
$$

Next - by way of the classic method of least squares - the structural parameters of the function in each segment are estimated. The number of segments in the series equals $n-k+1$, e.g. for a series comprising 60 values, with the constant $k=15$ years, the number of segments is 46 . The linear functions of the trend for each segment are as follows:

$$
\begin{aligned}
& \hat{y}_{1}=a_{1}+b_{1} t \text { for } 1 \leq t \leq k \\
& \hat{y}_{2}=a_{2}+b_{2} t \text { for } 2 \leq t \leq k+1 \\
& \ldots \ldots \ldots \ldots . . \\
& \hat{y}_{n-k+1}=a_{n-k+1}+b_{n-k+1} t \text { for } n-k+1 \leq t \leq n
\end{aligned}
$$

The ultimate smoothing of a series is arrived at by calculating arithmetic means from the theoretical values. The analysis has been performed for the constant $k=15$ years.

\section{RESULTS AND DISCUSSION}

The transformation was applied to all the series for which the result of the Shapiro-Wilk test was positive i.e. there was no reason to reject the hypothesis $H_{0}: F_{(x)}^{\prime}=F_{0(x)}$ stating the convergence of the distribution function of a studied series with the that of the normal distribution, and to those whose result was negative i.e. there was a reason to reject the $H_{0}$ hypothesis - the distribution function of the studied series was not convergent with that of the normal distribution. The transformation was used for the series which displayed normal distribution (following the Shapiro-Wilk test) in order to verify whether the data distribution in the series would be additionally improved.

Figures 2 and 3 (Quantile - Quantile plot), frequently referred to as the quantile plot for the normal distribution, depict selected transformations of precipitation and discharges. It is a rule of a quantile plot that if the observations are derived from the normal distribution, the points are aligned along a straight line. The graph is also indicative of the degree of deviation from the normal distribution which characterises the series being compared, e.g. the skewness of the series.

Table 2 presents the values of the $\lambda$ parameter for all the studied series of precipitation data. For the monthly series three groups of series are evident:

- monthly series for the winter half-year - especially the series from December to April - for them, the $\lambda$ parameter achieves the highest values.

- monthly series: May, June and October - the $\lambda$ parameter achieves the lowest values.

- monthly series for the summer half-year - from July to September and in November - the $\lambda$ parameter achieves the values between those quoted above.

Table 3 presents the values of the $\lambda$ parameter for all the studied series of the river discharge. It is difficult to indicate any schematic ordering of the $\lambda$ parameter in this respect. What is worth emphasising, though, is the fact that the values of the $\lambda$ parameter 

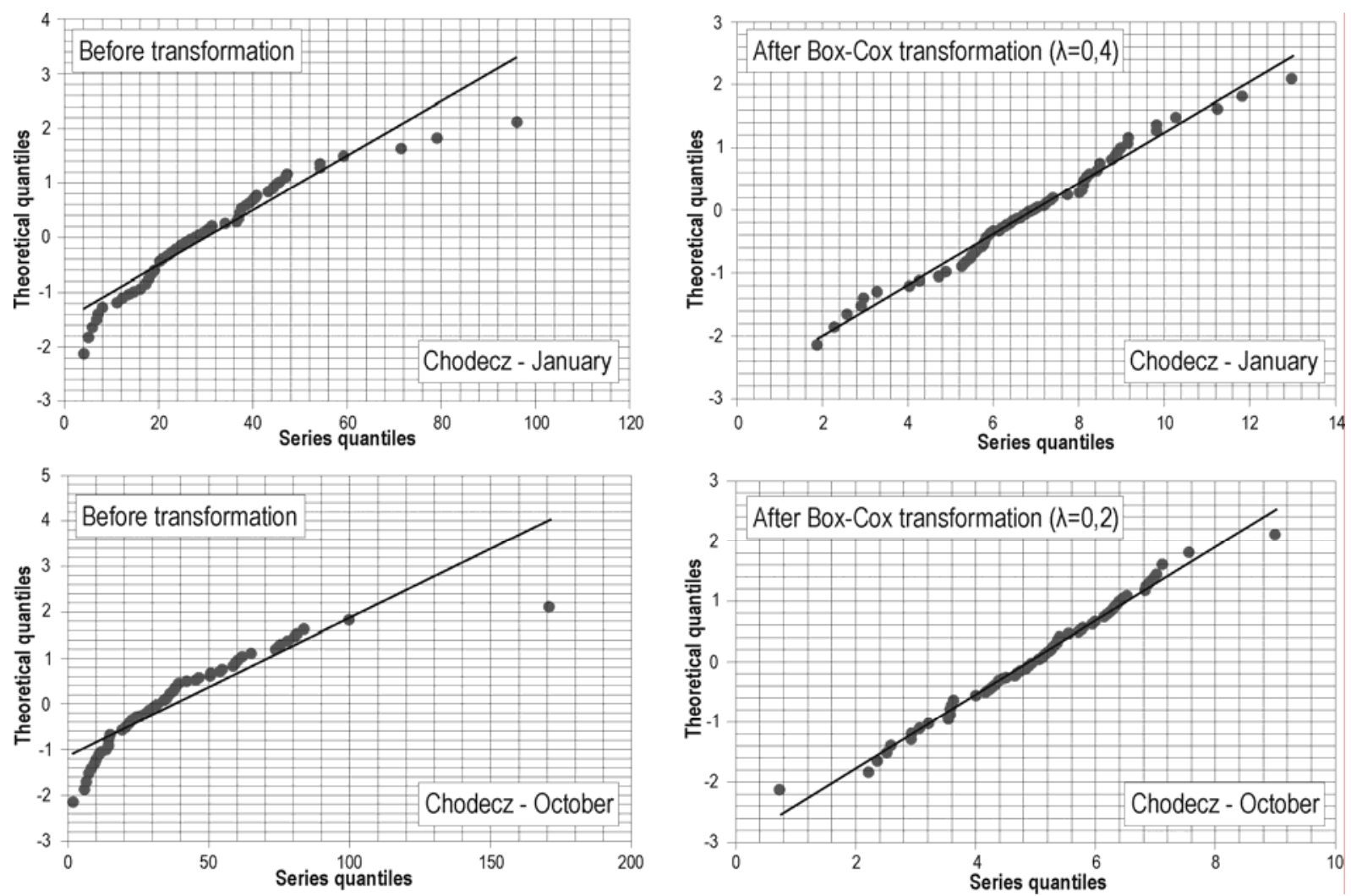

Fig. 2. $Q-Q$ plot for the normal distribution of selected series of monthly precipitation in Chodecz, Poland before and after Box-Cox transformation; source: own elaboration
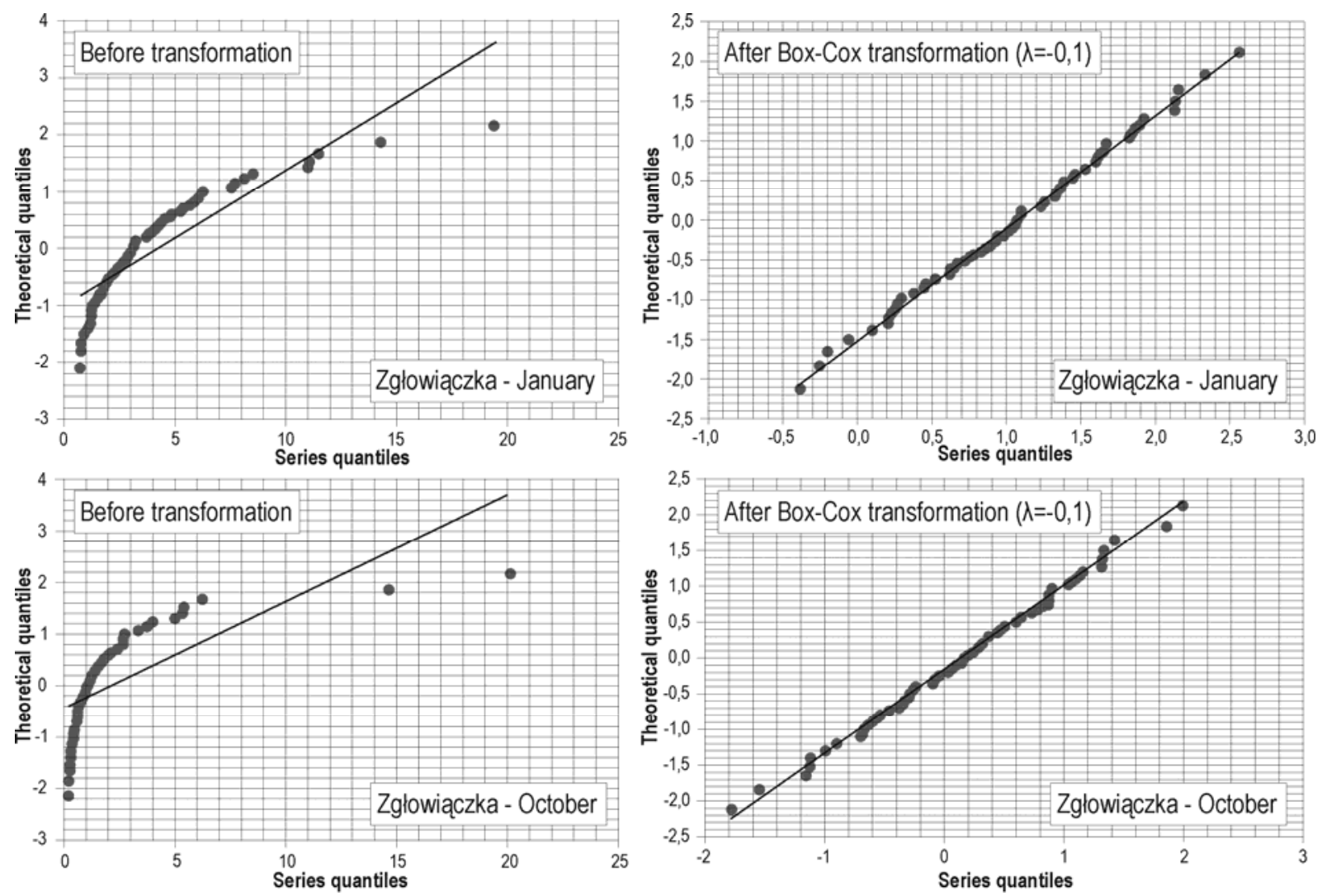

Fig. 3. $Q-Q$ plot for the normal distribution of selected series of mean monthly discharges of the Zgłowiączka river before and after Box-Cox transformation; source: own elaboration 
Table 2. Values of $\lambda$ parameter for the series of monthly, half-yearly, growing season and yearly precipitation

\begin{tabular}{|l|c|c|c|c|c|c|c|c|c|c|c|c|c|c|c|c|}
\hline $\begin{array}{c}\text { Precipitation } \\
\text { station }\end{array}$ & XI & XII & I & II & III & IV & V & VI & VII & VIII & IX & X & XI-IV & V-X & IV-IX & XI-X \\
\hline Baruchowo & 0.3 & 0.6 & 0.6 & 0.7 & 0.5 & 0.5 & 0.0 & 0.2 & 0.3 & 0.3 & 0.2 & 0.5 & 0.9 & -0.4 & -0.6 & -0.7 \\
\hline Chodecz & 0.6 & 0.5 & 0.4 & 0.9 & 0.8 & 0.4 & 0.2 & 0.3 & 0.5 & 0.3 & 0.3 & 0.2 & 1.0 & 0.4 & 0.5 & 1.0 \\
\hline Izbica Kuj. & 0.4 & 0.4 & 0.4 & 0.6 & 0.3 & 0.4 & 0.3 & 0.2 & 0.5 & 0.5 & 0.5 & 0.3 & 1.0 & 0.4 & 0.1 & 0.2 \\
\hline Gostynin & 0.2 & 0.9 & 0.9 & 0.6 & 0.4 & 0.4 & -0.1 & 0.2 & 0.3 & 0.4 & 0.3 & 0.2 & 1.0 & 0.7 & 0.2 & -0.3 \\
\hline Duninów & 0.3 & 0.6 & 0.5 & 0.5 & 0.8 & 0.5 & -0.2 & 0.1 & 0.2 & 0.5 & 0.2 & 0.2 & 0.8 & 0.0 & -0.7 & 0.8 \\
\hline Olganowo & 0.1 & 1.1 & 0.5 & 0.5 & 0.5 & 0.5 & 0.0 & 0.1 & 0.1 & -0.3 & 0.3 & -0.1 & 1.4 & 0.2 & -0.2 & 0.8 \\
\hline Brześć Kuj. & 0.5 & 0.8 & 0.7 & 0.3 & 0.6 & 0.7 & 0.2 & 0.4 & -0.1 & 0.1 & 0.5 & 0.1 & 0.9 & 1.0 & 1.1 & 1.2 \\
\hline Lubanie & 0.4 & 0.8 & 0.2 & 0.7 & 0.3 & 0.5 & 0.2 & 0.3 & 0.2 & 0.0 & 0.7 & 0.0 & -0.2 & 0.4 & 0.0 & 0.2 \\
\hline
\end{tabular}

Source: own elaboration.

Table 3. Values of $\lambda$ parameter for the series of monthly, half-yearly, growing season and yearly river discharges

\begin{tabular}{|l|c|c|c|c|c|c|c|c|c|c|c|c|c|c|c|c|}
\hline \multicolumn{1}{|c|}{ Rivers discharges } & XI & XII & I & II & III & IV & V & VI & VII & VIII & IX & X & $\begin{array}{c}\text { XI- } \\
\text { IV }\end{array}$ & V-X & $\begin{array}{c}\text { IV- } \\
\text { IX }\end{array}$ & XI-X \\
\hline $\begin{array}{l}\text { Zgłowiączka } \\
\text { (Włocławek Ruda gauge) }\end{array}$ & 0.1 & 0.1 & -0.1 & 0.3 & 0.1 & 0.2 & -0.1 & -0.2 & -0.3 & -0.3 & -0.3 & 0.0 & 0.2 & -0.2 & 0.0 & 0.3 \\
\hline $\begin{array}{l}\text { Lubieńka } \\
\text { (Nowa Wieś gauge) }\end{array}$ & 0.2 & 0.3 & -0.1 & 0.3 & 0.1 & 0.0 & -0.1 & -0.2 & -0.2 & 0.0 & -0.1 & 0.1 & 0.2 & -0.1 & -0.1 & 0.2 \\
\hline $\begin{array}{l}\text { Noteć } \\
\text { (Eysek gauge) }\end{array}$ & 0.1 & 0.2 & 0.1 & 0.2 & 0.1 & 0.1 & 0.1 & 0.2 & 0.0 & 0.1 & 0.2 & 0.1 & 0.2 & 0.1 & 0.1 & 0.4 \\
\hline $\begin{array}{l}\text { Skrwa Lewa } \\
\text { Klusek gauge) }\end{array}$ & 0.1 & -0.8 & -0.5 & -0.1 & -0.5 & -0.3 & -0.2 & -0.4 & 0.1 & 0.0 & -0.1 & 0.1 & -0.4 & -0.1 & -0.2 & 0.1 \\
\hline $\begin{array}{l}\text { Tażyna } \\
\text { (Otłoczynek gauge) }\end{array}$ & -0.1 & -0.3 & -0.2 & -0.1 & -0.2 & 0.0 & 0.1 & 0.0 & 0.0 & 0.1 & 0.1 & 0.1 & -0.2 & -0.1 & -0.1 & 0.0 \\
\hline
\end{tabular}

Source: own elaboration.

for the discharge are significantly lower than are those for precipitation as they are close to zero, which might indicate a higher level of skewness of the series. The values of the $\lambda$ parameter borderline zero, which indicates a logarithmic transformation of the variables, however, the $\lambda$ value is also in the negative territory hence it is necessary to apply a reverse transformation in order to align the elements of the series correctly.

The determined $\lambda$ parameters are of different values, which calls for the application of power transformations with various exponents for monthly precipitation series. It is of primary importance as in drive to select the most precise transformation it is not necessary to assume a priori one function transforming all the series of monthly precipitation. A similar approach should be adopted for river discharge series.

In the case of monthly precipitation series there is a statistically significant relation between the $\lambda$ parameter and the skewness of the series. This relation has been described by means of the Spearman's rank correlation method on the significance level of $p$-value $<0.05$ the relation has been identified by:

- grouping the $\lambda$ parameter and the related skewness for all the monthly series from the winter half-year period $\left(r_{s}=-0.62\right)$.

- grouping the $\lambda$ parameter and the related skewness for all the monthly series from the summer half-year period $\left(r_{s}=-0.68\right)$.

- grouping the $\lambda$ parameter and the related skewness for all the monthly series from the whole year pe$\operatorname{riod}\left(r_{s}=-0.76\right)$.
Hence, the higher the skewness, the lower the value of the $\lambda$ parameter. The series for NovemberMarch precipitation (winter series) display a lower level of skewness than do those for July-October (summer series). Therefore, it appears necessary to adopt a higher value of the $\lambda$ parameter so that the winter-period series are transformed to the series convergent with the normal distribution. The summer-period series, on the other hand, require lower values of the $\lambda$ parameter used for the transformation. The series for April-June period are characterised by the highest levels of skewness, that is why, the values of the $\lambda$ parameter are the lowest for these months.

For river discharges the correlation between the skewness of the series and the $\lambda$ parameter occurred by:

- grouping the $\lambda$ parameter and the related skewness for all the monthly series from the winter half-year period $\left(r_{s}=-0.51\right)$.

- grouping the $\lambda$ parameter and the related skewness for all the monthly series from the whole year pe$\operatorname{riod}\left(r_{s}=-0.36\right)$.

The $p$-value of the Shapiro-Wilk test can prove an interesting form of the correct and the best selection of the transformation function. The $p$-value is defined as the borderline level of the test significance at which the $H_{0}$ hypothesis is not rejected. It is frequently used in statistics as a measure of probability of making a type I error, which is rejecting a null hypothesis in case when it is true.

Table 4 presents the $p$-values for the ShapiroWilk test before and after the transformation. The 
Table 4. $P$-value of the Shapiro-Wilk test for the series of precipitation before and after Box-Cox transformation

\begin{tabular}{|c|c|c|c|c|c|c|c|c|c|c|c|c|c|c|c|c|}
\hline \multirow{2}{*}{ Month } & \multicolumn{2}{|c|}{ Baruchowo } & \multicolumn{2}{|c|}{ Chodecz } & \multicolumn{2}{|c|}{ Izbica Kuj. } & \multicolumn{2}{|c|}{ Gostynin } & \multicolumn{2}{|c|}{ Duninów } & \multicolumn{2}{|c|}{ Olganowo } & \multicolumn{2}{|c|}{ Brześć Kuj. } & \multicolumn{2}{|c|}{ Lubanie } \\
\hline & before & after & before & after & before & after & before & after & before & after & before & after & before & after & before & after \\
\hline $\mathrm{XI}$ & 0.0005 & $0.5700^{*}$ & $0.2330^{*}$ & 0.9995* & 0.0385 & 0.5233* & 0.0135 & $0.6089^{*}$ & 0.0087 & 0.7964* & $0.0544^{*}$ & $0.9375^{*}$ & $0.1217^{*}$ & $0.5222 *$ & $0.0738^{*}$ & $0.8197^{*}$ \\
\hline XII & 0.0503* & $992 *$ & 299 & 643* & 0.0234 & $886^{*}$ & $0.4389 *$ & 0.5104* & $1495^{*}$ & 0.5993* & 0.4033* & $0.4095^{*}$ & $0.1493^{*}$ & $0.1892 *$ & $0.4666 *$ & $6743^{*}$ \\
\hline I & 0.0113 & $0.7412^{*}$ & 0.0009 & 0.6947* & 0.0026 & $0.8647^{*}$ & 4317* & $0.5177^{*}$ & 0.0099 & 0.7790* & $0.1759^{*}$ & 0.5321* & $0.2780^{*}$ & $0.6072 *$ & 0.0038 & $0.7210^{*}$ \\
\hline II & $0.2809^{*}$ & $0.8535^{*}$ & $0.3452^{*}$ & $0.4523^{*}$ & 0.0097 & 0.4204* & $0.1177^{*}$ & $0.9945^{*}$ & 0.0056 & 0.5681* & 0.0279 & 0.9273* & \begin{tabular}{|l|}
0.0079 \\
\end{tabular} & 0.7618* & 0.4407* & $0.9447^{*}$ \\
\hline III & 0.0152 & 0.0596* & $0.3739^{*}$ & 0.7986* & 0.0257 & $0.4344^{*}$ & 0.1107* & $0.9055^{*}$ & $0.5008^{*}$ & $0.6300^{*}$ & 0.0442 & $0.6242 *$ & $0.2088^{*}$ & $0.7675^{*}$ & 0.0205 & $0.7621^{*}$ \\
\hline IV & 0.0144 & 0.8783* & 0.0021 & $0.8707^{*}$ & 0.0009 & 0.7336* & 0.0018 & 0.4538* & 0.0004 & 0.3902* & 0.0107 & $0.3479 *$ & $0.1452 *$ & $0.4863 *$ & 0.0011 & 0.6204* \\
\hline $\mathrm{V}$ & 0.0000 & $0.6651 *$ & 0.0001 & $0.4427^{*}$ & 0.0001 & $0.7729 *$ & 0.0000 & $0.6100^{*}$ & 0.0000 & $0.8948 *$ & 0.0124 & $0.6250^{*}$ & 0.0125 & 0.9384* & 0.0002 & $0.7240^{*}$ \\
\hline VI & 0.0000 & $0.9167^{*}$ & 0.0014 & \begin{tabular}{|l|}
$0.8205^{*}$ \\
\end{tabular} & 0.0002 & 0.8203* & 0.0001 & 0.1903* & 0.0002 & $0.9811^{*}$ & 0.0044 & 0.9934* & $0.0577^{*}$ & $0.9659 *$ & 0.0000 & 0.1923* \\
\hline VII & 0.0046 & $0.8480 *$ & $0.0767^{*}$ & $0.7143^{*}$ & 0.0443 & $0.3977 *$ & 0.0027 & $0.7475^{*}$ & 0.0045 & $0.9714 *$ & 0.0108 & $0.5567 *$ & 0.0001 & $0.4463^{*}$ & 0.0020 & $0.9569^{*}$ \\
\hline VIII & 0.0041 & $0.9472 *$ & 0.0006 & $0.8541^{*}$ & 0.0278 & $0.7256^{*}$ & 0.0028 & $0.3370^{*}$ & 0.0154 & $0.2815^{*}$ & 0.0034 & $0.8625^{*}$ & 0.0028 & $0.8348^{*}$ & 0.0000 & $0.5083^{*}$ \\
\hline IX & 0.0000 & $0.2537^{*}$ & 0.0001 & 0.3192* & 0.0037 & $0.9611^{*}$ & 0.0007 & $0.3316^{*}$ & 0.0000 & 0.9773* & 0.0076 & $0.6042 *$ & $0.1823^{*}$ & $0.9360^{*}$ & $0.3832^{*}$ & $0.9196 *$ \\
\hline $\mathrm{X}$ & 0.0007 & 0.9829* & 0.0000 & $0.9776 *$ & 0.0000 & $0.9937^{*}$ & 0.0008 & 0.5003 * & 0.0000 & $0.9640 *$ & 0.0001 & 0.9993* & 0.0000 & $0.9659 *$ & 0.0000 & $0.9195 *$ \\
\hline XI-IV & 0.3830* & 0.3830* & $0.3191 *$ & 0.3191* & $0.5055^{*}$ & $0.5055^{*}$ & $0.2240^{*}$ & $0.2240^{*}$ & $0.6196 *$ & 0.6996* & 0.5261* & 0.6291* & $0.9992^{*}$ & $0.9995^{*}$ & $0.0739 *$ & 0.8861* \\
\hline $\mathrm{V}-\mathrm{X}$ & 0.0064 & 0.2904* & $0.2904 *$ & $0.6976^{*}$ & 0.7154* & $0.9987^{*}$ & $0.8337^{*}$ & 0.9338* & $0.0927^{*}$ & $0.3839^{*}$ & $0.2985^{*}$ & $0.5759^{*}$ & $0.6335^{*}$ & $0.6335^{*}$ & $0.4343^{*}$ & 0.6603* \\
\hline IV-IX & 0.0007 & $0.5505^{*}$ & $0.5505^{*}$ & 0.9286* & 0.0796* & 0.9216* & $0.4517^{*}$ & $0.9955^{*}$ & 0.0038 & 0.2738* & $0.2603^{*}$ & 0.9696* & $0.9856^{*}$ & $0.9866^{*}$ & $0.2609 *$ & 0.9714* \\
\hline $\mathrm{XI}-\mathrm{X}$ & 0.0114 & $0.8180 *$ & $0.8180^{*}$ & $0.8180^{*}$ & $0.4564 *$ & $0.8926^{*}$ & 0.3201* & 0.9708* & $0.6986^{*}$ & 0.7334* & $0.4965^{*}$ & $0.5147^{*}$ & $0.7456^{*}$ & $0.7772^{*}$ & $0.4952^{*}$ & $0.8589^{*}$ \\
\hline
\end{tabular}

Explanation: * - statistically significant.

Source: own elaboration.

information that can be inferred from the table is of double nature. In which months and how many series had the distribution convergent with the normal one and what is the accuracy of the performed transformation.

For monthly precipitation distributions a certain pattern can be observed. In most cases (approx. 92\%) the distributions were not of a normal pattern in the summer half-year months (May-October). In the winter half-year months (November-April) the structure was nearly balanced with approx. $46 \%$ of the series having the normal distribution and 54\% displaying other distribution patterns. The transformation caused all the monthly precipitation series for whichever half-year period to be normalised.

In the case of the distributions of the mean discharges series (monthly, half-yearly, yearly and concerning the growing season) none of them was convergent with the normal distribution (Tab. 5). After the transformation, most of them $(94.6 \%)$ were normalised as well.

Table 5. $P$-value of the Shapiro-Wilk test for the series of mean river discharges before and after Box-Cox transformation

\begin{tabular}{|c|c|c|c|c|c|c|c|c|c|c|}
\hline \multirow[t]{2}{*}{ Month } & \multicolumn{2}{|c|}{$\begin{array}{c}\text { Zgłowiączka } \\
\text { (Włocławek Ruda } \\
\text { gauge) }\end{array}$} & \multicolumn{2}{|c|}{$\begin{array}{c}\text { Lubieńka } \\
\text { (Nowa Wieś gauge) }\end{array}$} & \multicolumn{2}{|c|}{$\begin{array}{c}\text { Noteć } \\
\text { (Lysek gauge) }\end{array}$} & \multicolumn{2}{|c|}{$\begin{array}{c}\text { Skrwa Lewa } \\
\text { (Klusek gauge) }\end{array}$} & \multicolumn{2}{|c|}{$\begin{array}{c}\text { Tążyna } \\
\text { (Otłoczynek gauge) }\end{array}$} \\
\hline & before & after & before & after & before & after & before & after & before & after \\
\hline XI & 0.0000 & 0.3586* & 0.0028 & 0.1569* & 0.0002 & 0.3489* & 0.0008 & 0.6349* & 0.0000 & 0.8881* \\
\hline XII & 0.0000 & $0.8350 *$ & 0.0045 & 0.0244 & 0.0001 & $0.4187 *$ & 0.0000 & $0.2652 *$ & 0.0000 & $0,1790 *$ \\
\hline I & 0.0000 & $0.9604 *$ & 0.0000 & $0.5569 *$ & 0.0000 & $0.9882 *$ & 0.0000 & $0.9162 *$ & 0.0000 & $0.3507 *$ \\
\hline II & 0.0002 & 0.7977* & 0.0049 & 0.5431* & 0.0005 & $0.6203^{*}$ & 0.0000 & $0.5010 *$ & 0.0000 & 0.8045* \\
\hline III & 0.0000 & $0.9822 *$ & 0.0000 & 0.5238* & 0.0001 & $0.4462 *$ & 0.0000 & $0.8153 *$ & 0.0000 & $0.5401 *$ \\
\hline IV & 0.0000 & $0.6365^{*}$ & 0.0000 & 0.0128 & 0.0000 & $0.0761^{*}$ & 0.0000 & 0.0125 & 0.0000 & 0.9881* \\
\hline $\mathrm{V}$ & 0.0000 & $0.8651^{*}$ & 0.0000 & $0.8182 *$ & 0.0000 & $0.1015^{*}$ & 0.0000 & $0.5309 *$ & 0.0000 & 0.7571* \\
\hline VI & 0.0000 & $0.8050 *$ & 0.0000 & $0.9240 *$ & 0.0000 & $0.4545^{*}$ & 0.0000 & $0.4374 *$ & 0.0000 & $0.0975^{*}$ \\
\hline VII & 0.0000 & 0.8211* & 0.0000 & 0.7210* & 0.0000 & 0.0438 & 0.0000 & 0.7990* & 0.0000 & 0.0099 \\
\hline VIII & 0.0000 & 0.9953* & 0.0000 & $0.8205 *$ & 0.0000 & 0.5598* & 0.0000 & 0.8589* & 0.0000 & 0.2198* \\
\hline IX & 0.0000 & $0.4787^{*}$ & 0.0000 & $0.8255^{*}$ & 0.0000 & $0.9606^{*}$ & 0.0000 & $0.9586 *$ & 0.0000 & $0.8246^{*}$ \\
\hline $\mathrm{X}$ & 0.0000 & $0.3507^{*}$ & 0.0002 & 0.7903* & 0.0000 & $0.8145^{*}$ & 0.0003 & $0.8927 *$ & 0.0000 & $0.9947^{*}$ \\
\hline XI-IV & 0.0005 & $0.3151 *$ & 0.0127 & 0.7201* & 0.0037 & $0.5274 *$ & 0.0002 & $0.7732 *$ & 0.0000 & $0.3554 *$ \\
\hline $\mathrm{V}-\mathrm{X}$ & 0.0000 & 0.8281* & 0.0000 & 0.9886* & 0.0000 & $0.5135^{*}$ & 0.0001 & $0.5155^{*}$ & 0.0000 & $0.4997^{*}$ \\
\hline IV-IX & 0.0000 & $0.9751 *$ & 0.0000 & 0.7127* & 0.0000 & 0.2309* & 0.0001 & $0.9405 *$ & 0.0000 & 0.8879* \\
\hline XI-X & 0.0036 & $0.6351 *$ & 0.0333 & $0.4615 *$ & 0.0400 & $0.6882 *$ & 0.0222 & 0.3584* & 0.0000 & $0.7176 *$ \\
\hline
\end{tabular}

Explanation: * - statistically significant.

Source: own elaboration.

The results presented in Tables 4 and 5 unambiguously indicate that the accuracy of the transformation performed with the Box-Cox method is very high and it is true for both precipitation and discharge series. The accuracy concerns each of the series - monthly, half-yearly and yearly values as well. This situation derives from the fact that during the analysis process each of the series was given an individual consideration. Each one of them was individually subjected to the process of searching the best transformation function. 
The results of the homogeneity of the variance of the series after the transformation also proved to be highly satisfactory both for precipitation and river discharges. Out of 96 series for monthly precipitation $16(19.7 \%)$ were not homogenous in terms of variance before the transformation. What was characteristic was the disproportion between the non-homogeneous precipitation series for the winter months and the summer ones. Lack of homogeneity was more frequently identified in the summer months - 13 times, with only 3 times in the case of the winter half-year period. All the remaining series i.e. yearly, half-yearly and for the growing season were homogeneous before the transformation. After the transformation merely two series for monthly precipitation remained non-homogeneous, which makes approx. $2 \%$ of the total number of values and remains within the realm of the statistical error. Equally good results were obtained for river discharge series. It should be made clear that before the transformation the series of mean monthly discharges were not homogeneous in 42 cases $(80 \%$ of their total value). The series of mean discharges for the summer and the growing season months were of non-homogeneous nature while those for the winter months and the whole year were homogeneous.

After the transformation only 5 series of mean monthly discharges remained non-homogeneous.

The entire series normalisation and standardisation process made it possible to identify dry periods, which goes along a specific scheme. MCKeE et al. [1993] suggest that a dry period be described by the values of the series after normalisation and standardisation which fall in the range between 0.0 and -0.99 . They referred to such an event as a mild drought. Consequently, the range -1.00 to -1.49 was classified as a moderate drought, -1.50 to -1.99 as a severe drought and $\leq-2.00$ as an extreme drought. In subsequent works, among others GUTTMAN [1999], the classification of dry and wet periods was made following the scheme presented in Table 6. BAK, LABĘDZKI [2003] and ŁABĘDZKI [2006], however, point out the need for this classification to be modified so that the threshold value was set at -0.5 . Again, they refer to such an event as a mild drought. The change is justified by the fact that the shortage of rainfall occurring in these periods may affect the growth of plants, particularly in agricultural areas.

Table 6. Classification of a drought expressed with the $S P I$

\begin{tabular}{|l|c|}
\hline \multicolumn{1}{|c|}{ Drought category } & SPI classification \\
\hline Extremely wet & 2.00 or more \\
\hline Very wet & 1.50 to 1.99 \\
\hline Moderately wet & 1.00 to 1.49 \\
\hline Near normal & 0.99 to -0.99 \\
\hline Moderately dry & -1.00 to -1.49 \\
\hline Severely dry & -1.50 to -1.99 \\
\hline Extremely dry & -2.00 and less \\
\hline
\end{tabular}

Source: acc. to GUTTMAN [1999].
Due to agricultural bias of the studied area, Figure 4 depicts the results obtained for precipitation and discharge in the growing period. In order to facilitate the distinction between the normalised, standardised and classified values, in respect of precipitation they have been denoted SPI (Standardized Precipitation Index) and for discharges - SDI (Standardized Discharge Index). The shape of the line of the moving trend indicates intertwining occurrence of dry and wet periods. What is characteristic is the appearance of periods of greater and smaller precipitation and discharge values in relation to their mean value. There seems to be a high degree of convergence between the periods of atmospheric and hydrological droughts. It might be assumed, then, that the fluctuations and short-term (several years) precipitation trends have a greater impact on the development of agriculture in this area than do the long-term trends.

\section{CONCLUSIONS}

The Box-Cox method applied for the sake of this analysis met all the initial assumptions. Its universal character enabled precise calibration of the transformation of series of various data - precipitation and river discharges. With this technique, the best transformation function for the studied series was selected. It also made it possible to homogenise the series in terms of variance. Therefore, it should be assumed that the method can be applied to perform transformations of other series of nature-related data. Owing to the application of the Box-Cox transformation, the complex, though standard, stage of analyses - the evaluation of the probability density function for input data - was omitted.

The analysis of the relation between the series skewness and the transformation function parameter in the case of monthly precipitation proved it to be statistically significant. The authors, believe, though, that these results must be confirmed using a substantially wider base of data series.

It must be mentioned, as well, that the automatic and only one parameter of transformation of all the series of data does not guarantee the same distribution pattern - the normal distribution of the transformed data as a result. This is particularly true for the series of monthly values.

Owing to the series having been normalised and standardised, the periods of droughts in the growing season in the agricultural area were possible to be identified and classified.

\section{Acknowledgements}

The results presented herein are a part of the work financed from the science funds for 2010-2013 as a research project N N306 4735 38. The analyses were also conducted with the support from project ICLEA (The study is a contribution to the Virtual Institute of Integrated Climate and Landscape Evolution of the Helmholtz Association). 


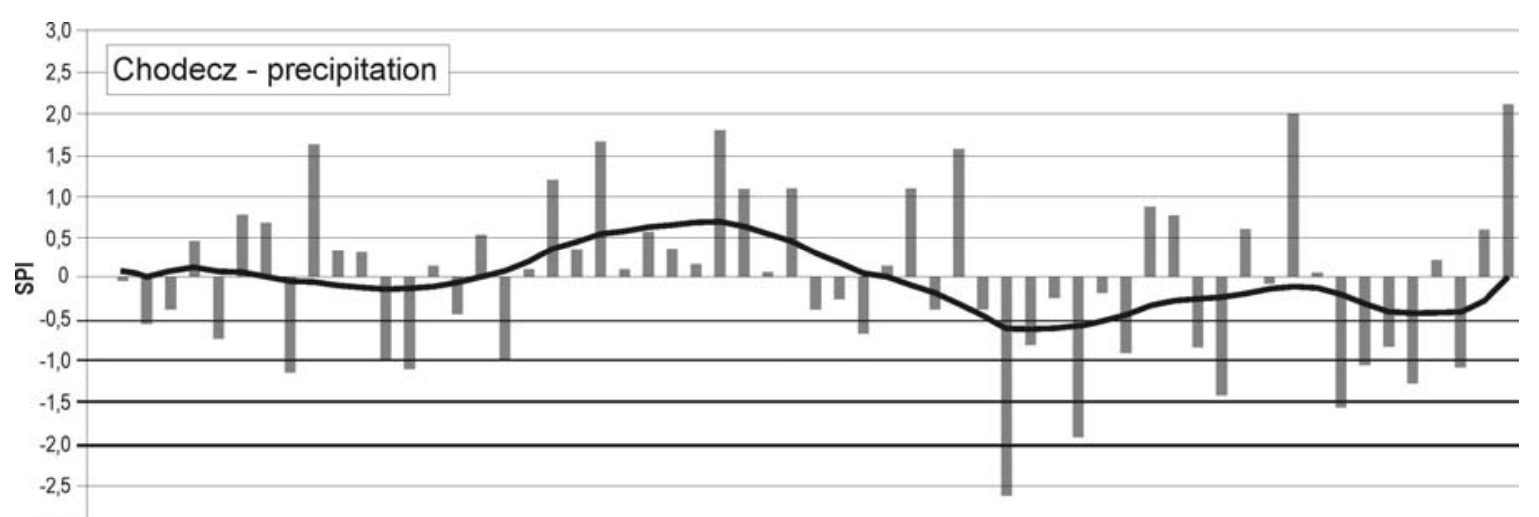

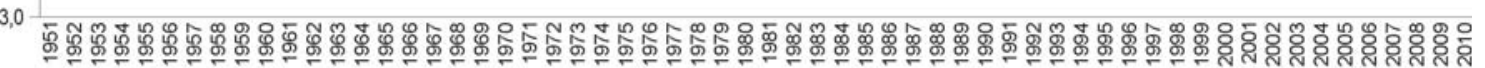

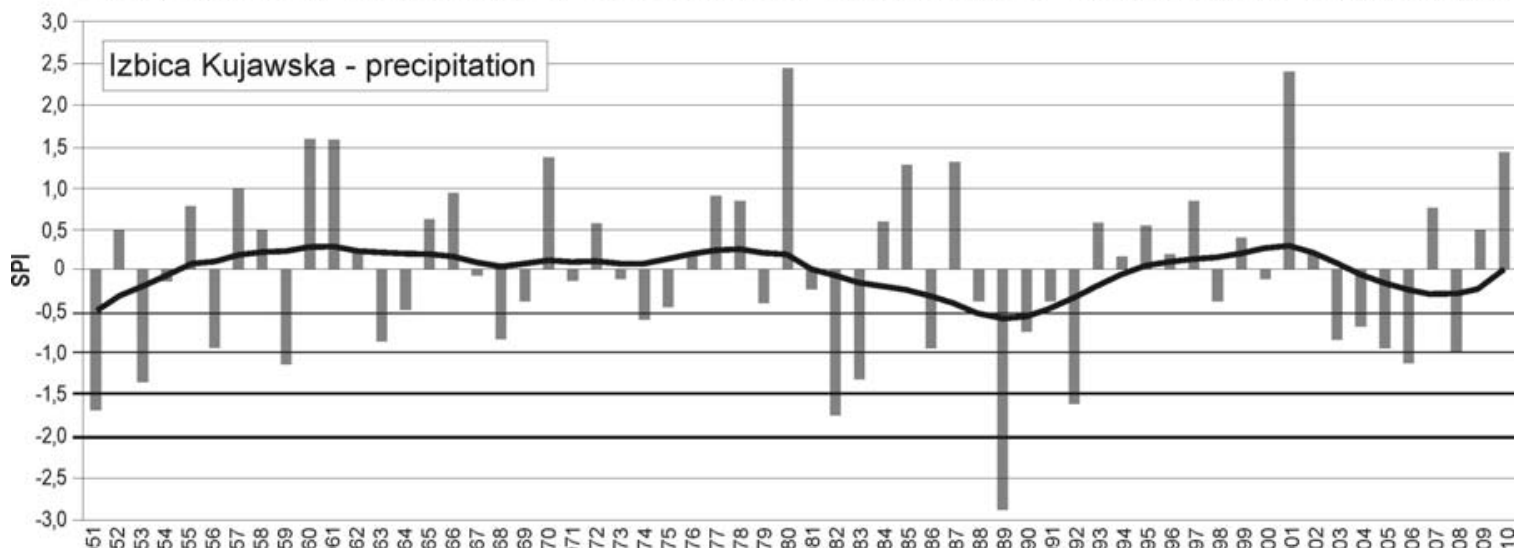

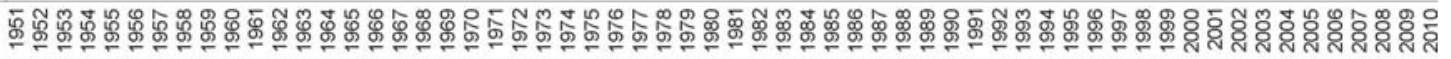
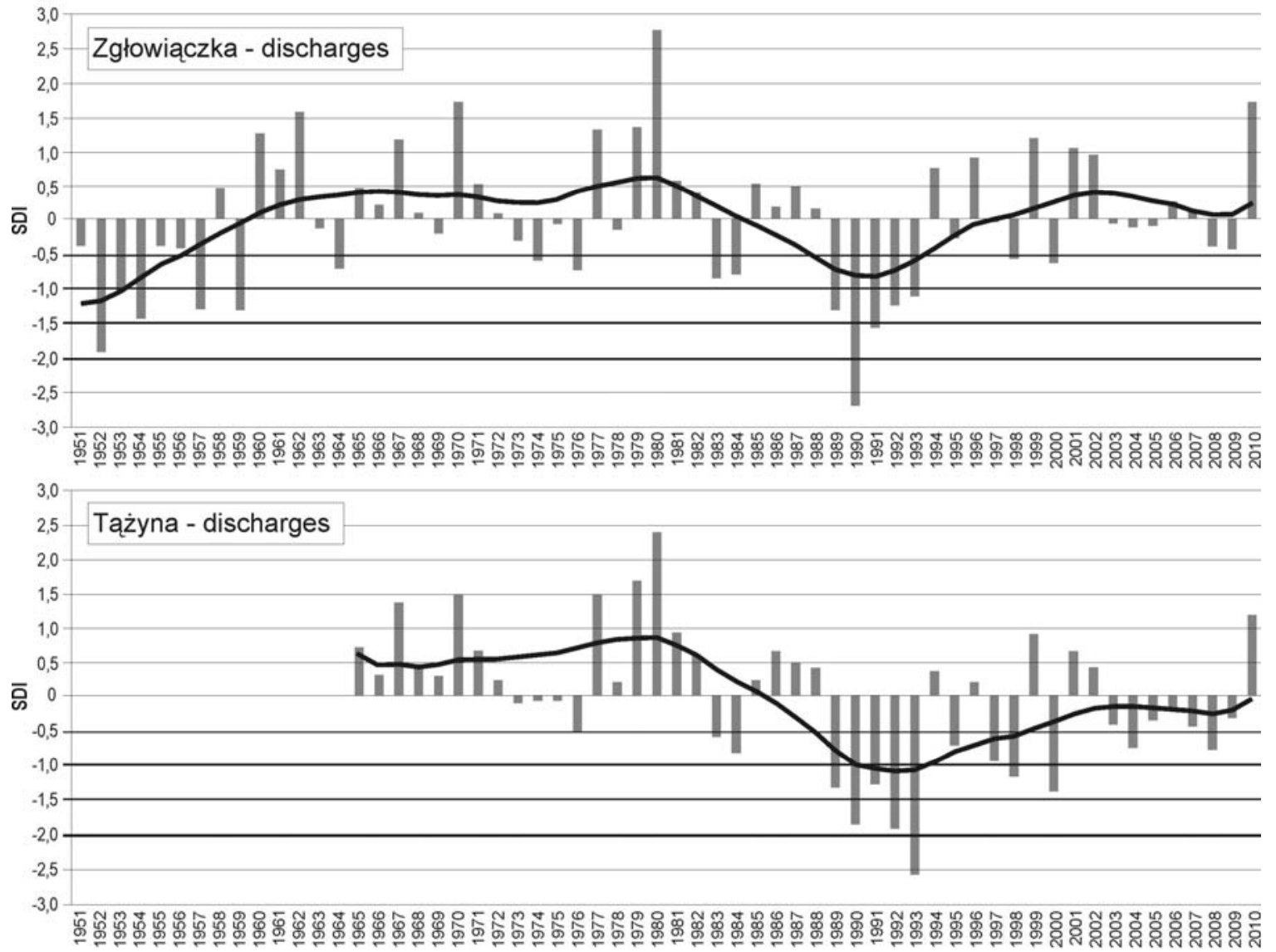

Fig. 4. Values of SPI (Standardised Precipitation Index) and SDI (Standardised Discharge Index) and their trends at selected precipitation stations and water gauges in the growing period 1951-2010; source: own elaboration 


\section{REFERENCES}

BARTCZAK A. 2007. Wieloletnia zmienność odpływu rzecznego $\mathrm{z}$ dorzecza Zgłowiączki [Long-term variability of the river outflow from the Zgłowiączka basin]. Prace Geograficzne IGiPZ PAN. Nr 209. ISBN 978-83-8795496-6 pp. 164.

BARTCZAK A., BRYKala D. 2010. Warunki hydrologiczne w rejonie planowanej odkrywki węgla brunatnego "Tomisławice" KWB "Konin" S.A. W: Antropogeniczne i naturalne przemiany środowiska geograficznego województwa kujawsko-pomorskiego - wybrane przykłady [Hydrological conditions in the area of the planned "Tomisławice" lignite trip mine Brown Coal Mine "Konin" S.A. In: Antropogenic and natural changes of geographical environment in the Kuyavian-Pomeranian voivodship - selected examples]. Eds. J. Kordowski, D. Brykała. Prace Geograficzne IGiPZ PAN. Nr 223 p. 11-44.

BARTCZAK A., GlaziK R., TYSZKOWSKI S. 2013. Tendencje rocznych sum opadów atmosferycznych we wschodniej części Kujaw [Trends of yearly precipitation for Eastern Kujawy]. Nauka Przyroda Technologie. T. 7. Z. 1 p. $1-18$.

BARTLETT M.S. 1947. The use of transformations. Technometrics. Vol. 3. No. 1 p. 39-52.

BAূK B., ŁABĘDZKI L. 2002. Assessing drought severity with the relative precipitation index $(R P I)$ and the standardized precipitation index $(S P I)$. Journal of Water and Land Development. No. 6 p. 29-49.

BĄK B., ŁABĘDZKI L. 2003. Modification of Standardized Precipitation Index SPI for drought monitoring in Poland. In: Meteorological services' tasks in NATO operations, missions and exercises. 5th International Symposium on Military Meteorology. Poznań, 29.09-02.10.2003. Warszawa. WAT p. 15-22.

Bonnacorso B., Boroli I., CANCIEllere A., Rossi G., SUTERA A. 2003. Spatial variability of drought; an analysis of the SPI in Sicily. Water Resources Management. Vol. 17 p. 273-296.

Box G.E.P., Cox D.R. 1964. An analysis of transformations. Journal of the Royal Statistical Society. Ser. B (Methodological). Vol. 26. No. 2 p. 211-252.

Box G.E.P., Cox D.R. 1982. An analysis of transformations Revisited, Rebutted. Journal of the Royal Statistical Association. Vol. 77. No. 377 p. 209-210.

BRENDA Z. 1997. Deficyt wody - główna bariera wzrostu produkcji rolnej w województwie włocławskim Włocławek Voivodship [The chosen issues of water economy against the background of natural and anthropogenic conditions]. Przegląd Geograficzny. T. 69. Z. 3-4 p. 333351.

BrykatA D. 2009. Przestrzenne i czasowe zróżnicowanie odpływu rzecznego w dorzeczu Skrwy Lewej [Spatial and time differentiation of river discharge within the Skrwa Lewa river basin]. Prace Geograficzne IGiPZ PAN. Nr 221. ISBN 978-83-61590-11-8 pp. 142.

Caravitis Ch.A., Alexandris S., Tsemelis D.E., AthanaSOPOUlOS G. 2011. Application of the Standardized Precipitation Index $(S P I)$ in Greece. Water. 3. DOI: 10.3390/w3030787 p. 787-805.

CosTA A.C. 2011. Local patterns and trends of the Standard Precipitation Index in southern Portugal (1940-1999). Advances in Geosciences. Vol. 30. DOI: 10.5194/adgeo30-11-2011 p. 11-16.

Dingens P., SteYAeRT H. 1971. Distribution for $k$-day rainfall totals. Bulletin of the International Association of Scientific Hydrology. Vol. 16. Iss. 3 p. 19-24.
Dutra E., Di Giuseppe F., Wettrhall F., Pappenberger F. 2013. Seasonal forecasts of droughts in African Basins using the Standardized Precipitation Index. Hydrology and Earth System Sciences. Vol. 17 p. 2359-2373.

GIERSZEWSKI P. 2000. Charakterystyka środowiska hydrochemicznego wód powierzchniowych zachodniej części Kotliny Płockiej [Characteristics of hydro-chemical environment of surface waters in the western part of the Płock basin]. Prace Geograficzne IGiPZ PAN. Nr 176. ISBN 83-86682-49-3 pp. 136.

GRIFFITHS G.A. 1989. A theoretically based Wakeby distribution for annual flood series. Hydrological Sciences Journal/Journal des Sciences Hydrologiques. Vol. 34. Iss. 3 p. $231-248$.

GutTMAN N.B. 1999. Accepting the Standardized Precipitation Index: a calculation algorithm. Journal of the American Water Resources Association. Vol. 35. No. 2 p. 311-322.

He W., Wan S., Jiang Y., Jin H., Zhang W., Wu Q., He T. 2013. Detecting abrupt change on basis of skewness: numerical test and applications. International Journal of Climatology. Vol. 33. DOI: 10.1002/joc.3624 p. 27132727.

HoYLE M.H. 1973. Transformations - An introduction and a bibliography. International Statistical Review. Vol. 41. No. 2 p. 203-223.

JAHANGIR AlAM A.T.M., SAYEDUR RAHMAN R., SAADAT A.H.M. 2013. Monitoring meteorological and agricultural drought in Barind region Bangladesh using standard precipitation index and Markov chain model. International Journal of Geomatics and Geosciences. Vol. 3. No. 3 p. $511-524$.

JOKIEL P. 2007. Przepływy ekstremalne wybranych rzek środkowej Polski w latach 1951-2000. W: Zjawiska ekstremalne i zdarzenia nadzwyczajne w środkowej Polsce [Extreme discharges of selected rivers in central Poland in 1951-2000. In: Extreme phenomena and exceptional events in Central Poland]. Ed. P. Jokiel. Acta Universitatis Lodziensis. Folia Geographica Physica 8. ISSN 14279711 p. $99-129$.

KendALL G.R. 1960. The cube-root-normal distribution applied to Canadian monthly rainfall totals. Publication de l'Association Internationale d'Hydrologie Scientifique. Vol. 53 p. $250-260$.

Khadr M., Morgenschweis G., Schlenkhoff A. 2009. Analysis of meteorological drought in the Ruhr Basin by using Standardized Precipitation Index. World Academy of Science. Engineering and Technology. Vol. 57 p. 607619.

Khan M.A., Gadiwala M.S. 2013. A study of drought over Sindh (Pakistan) using Standardized Precipitation Index 1951-2010. Pakistan Journal of Meteorology. Vol. 9. Iss. 18 p. $15-22$

KoŻUCHOWSKI K. 1985. Zmienność opadów atmosferycznych w Polsce w stuleciu 1881-1980 [Variation in precipitation in the years 1881-1980 in Poland]. Acta Geographica Lodziensia. 48 pp. 158.

KrężAŁeK K., SzymcZAK T., BĄK B. 2013. Maksymalne roczne sumy dobowe opadów o określonym prawdopodobieństwie przewyższenia na obszarze środkowej Polski na podstawie danych $\mathrm{z}$ wielolecia 1966-2010 [The annual maximum daily rainfall with different probabilities of exceedance in Central Poland based on data from the multiannual period 1966-2010]. Woda-Środowisko-Obszary Wiejskie. T. 13. Z. 4(44) p. 77-90. 
ŁABĘZZKI L. 2004. Problematyka susz w Polsce [Drought problems in Poland]. Woda-Środowisko-Obszary Wiejskie. T. 4. Z. 1 (10) p. 47-66.

ŁABĘDZKI L. 2006. Susze rolnicze. Zarys problematyki oraz metody monitorowania i klasyfikacji [Agricultural drought. An outline of problems and method of monitoring and classification]. Woda-Środowisko-Obszary Wiejskie. Rozprawy naukowe i monografie. Nr 17. ISBN 8388763-63-6 pp. 107.

ŁABĘDZKI L. 2007. Estimation of local drought frequency in Central Poland using the Standardized Precipitation Index SPI. Irrigation and Drainage. Vol. 56 p. 67-77.

ŁABĘDZKI L., BĄK B. 2002. Monitoring suszy za pomocą wskaźnika standaryzowanego opadu SPI [Monitoring of droughts using the Standardized Precipitation Index SPI]. Woda-Środowisko-Obszary Wiejskie. T. 2. Z. 2 (5) p. 9 19.

ŁabęDZKi L., BĄK B., KANECKA-GESZKe E., KASPERSKA-WoŁowicz W., SMARZYŃSKa K. 2008. Związek między suszą meteorologiczną i rolniczą $\mathrm{w}$ różnych regionach agroklimatycznych Polski [Relationship between meteorological and agricultural drought in different agroclimatic regions in Poland]. Woda-Środowisko-Obszary Wiejskie. Rozprawy naukowe i monografie. Nr 25. ISBN ISBN 978-83-61875-03-1 pp. 137.

McKee T.B., Doesken N.J., KLeIST J. 1993. The relationship of drought frequency and duration to time scales. Eighth Conference on Applied Climatology. 17-22 January 1993. Anaheim. California p. 179-184.

Mitosek H.T. 1997. Pewne właściwości procesu opadów dobowych na przykładzie danych puławskich [Some properties of daily precipitation process exemplified by $\mathrm{Pu}-$ ławy’s data]. Pamiętnik Puławski. Prace IUNG. Z. 110 p. 91-102.

Nelson H.L. Jr., Granger C.W.J. 1979. Experience with using the Box-Cox transformation when forecasting economic time series. Journal of Econometrics. Vol. 10 p. $57-69$.

OSBORNE J.W. 2010. Improving your data transformations: Applying the Box-Cox transformation. Practical Assessment, Research and Evaluation. Vol. 15. No 12 p. 1-9.
PARK J.S., JUNG H.S., KIM R.S., OH J.H. 2001. Modelling summer extreme rainfall over the Korean Penisula using Wakeby distribution. Modelling summer extreme rainfall over the Korean Penisula using Wakeby distribution. Vol. 21 DOI: 10.1002/joc.701 p. 1371-1384.

Paulo A.A., Rosa R.D., Pereira L.S. 2012. Climate trends and behavior of drought indices based on precipitation and evapotranspiration in Portugal. Natural Hazards and Earth System Sciences. Vol. 12. DOI: 10.5194/nhess-121481-2012 p. 1481-1491.

Peltier M.R., Wilcox C.J., Sharp D.C. 1998. Technical note: Application of the Box-Cox transformation to animal science experiments. Journal of Animal Science. Vol. 76 p. $847-849$.

SAKIA R.M. 1992. The Box-Cox transformation technique: a review. The Statistician. Vol. 41 p. 169-178.

SEN A.K., NiEDZIELSKI T. 2010. Statistical characteristics of riverflow variability in the Odra River basin, Southwestern Poland. Polish Journal of Environmental Studies. Vol. 19. No. 2 p. 387-397.

STRUPCZEWSKI W. 1967. Przekształcanie rozkładów zmiennych hydrologicznych i meteorologicznych do rozkładu normalnego [Transformation of variable hydrologic and meteorologic distributions to normal distribution]. Wiadomości Służby Hydrologicznej i Meteorologicznej. T. 3 (15). Z. 2(70) p. 15-26.

Su B., KundZewicz Z.W., JiAnG T. 2009. Simulation of extreme precipitation over the Yangtze River Basin using Wakeby distribution. Theoretical and Applied Climatology. Vol. 96. Iss. 3-4. DOI: 10.1007/s00704-008-0025-5 p. 209-219.

ThYer M., Kuczera G., Wang Q.J. 2002. Quantifying parameter uncertainty stochastic models using the Box-Cox transformation. Journal of Hydrology. Vol. 265 p. 246257.

Twardosz R., Walanus A. 2011. Praktyczne testowanie istotności różnicy wartości średnich w seriach opadowych [A practical method for testing of the significance of difference between average values in precipitation series]. Przegląd Geofizyczny. T. 56. Z. 1-2 p. 81-97.

\section{Arkadiusz BARTCZAK, Ryszard GLAZIK, Sebastian TYSZKOWSKI}

\section{Wykorzystanie przeksztalcenia Boxa-Coxa do wyznaczenia wskaźnika standaryzowanego opadu (SPI), wskaźnika standaryzowanego przepływu (SDI) oraz identyfikacji okresów suchych na przykładzie wschodniej części Kujaw (centralna Polska)}

\section{STRESZCZENIE}

Słowa kluczowe: homogeniczność szeregów, Kujawy Wschodnie, okresy suche, przeksztatcenie Boxa-Coxa, rozkład normalny, SDI, SPI, trend kroczacy

W artykule przedstawiono wyniki badań dotyczących transformacji szeregów danych hydro meteorologicznych w celu zidentyfikowania okresów suchych za pomocą wskaźnika standaryzowanego opadu (SPI) oraz wskaźnika standaryzowanego przepływu $(S D I)$. Analizie poddano szeregi z ośmiu posterunków opadowych oraz pięciu szeregów przepływów rzecznych z obszaru wschodniej części Kujaw (centralna Polska). Zakres analiz obejmował lata 1951-2010. Sprawdzenie rozkładu częstości szeregów pod kątem ich zgodności z rozkładem normalnym wykonano za pomocą testu Shapiro-Wilka, a homogeniczność szeregów zbadano testem Bartletta. Do przekształceń szeregów wybrano metodę Boxa-Coxa, której do tej pory nie stosowano do wyznaczania wskaźnika SPI. Praktycznie rozkłady wszystkich szeregów po przekształceniu wykazywały rozkład zgodny 
z rozkładem normalnym i były homogeniczne. Stwierdzono statystycznie istotny związek korelacyjny między parametrem transformacji $\lambda$ a skośnością szeregów miesięcznych sum opadów. Podobny związek stwierdzono w odniesieniu do szeregów średnich miesięcznych przepływów w półroczu zimowym i roku hydrologicznym. W efekcie obliczono wskaźniki SPI oraz SDI, a następnie zidentyfikowano okresy suche w okresach wegetacyjnych w badanym wieloleciu. Terminy występowania susz atmosferycznych były analogiczne z okresami występowania susz hydrologicznych. Prawdopodobnie fluktuacje, a także krótkookresowe tendencje opadów mają większe znaczenie dla rozwoju rolnictwa na tym obszarze niż ich tendencje wieloletnie. 